\author{
MIROSLAWA SAGAN-BIELAWA \\ Uniwersytet Jagielloński w Krakowie \\ ORCID: 0000-0003-2940-9259
}

\title{
O KORZYŚCIACH Z NAUCZANIA ORAZ UCZENIA SIE JĘZYKA POLSKIEGO JAKO OBCEGO (WYNIKI SONDAŻU)
}

Słowa kluczowe: polityka językowa, świadomość językowa, sondaż opinii publicznej, język polski jako język obcy, promocja języka polskiego.

\section{STRESZCZENIE}

Opracowanie stanowi kontynuację badań opinii na temat pozycji języka polskiego w świecie. Przeprowadzono je wśród 664 studentów Uniwersytetu Wrocławskiego, Uniwersytetu Jagiellońskiego, Akademii Górniczo-Hutniczej i Politechniki Śląskiej. Artykuł dotyczy pytań otwartych: „Dlaczego obcokrajowcy uczą się języka polskiego?” oraz „Czy Polska może mieć jakieś korzyści z faktu, że inni znają nasz język i posługują się nim?”. Respondenci dostrzegają utylitarną, marketingową, ale i poznawczą wartość języka jako klucza do kultury, tradycji i mentalności. Popularyzację polszczyzny wśród obcokrajowców uznają za pożyteczną dla wizerunku kraju i rozwoju gospodarczego. Ankieta pokazuje zróżnicowanie w poglądach na potencjał ekonomiczny języka i kultury, związane w pewnym stopniu z profilem i kierunkiem studiów.

Nauczanie języka polskiego jako obcego oraz związane z tym międzynarodowe egzaminy certyfikowane stanowią skuteczne elementy polityki językowej. Wraz ze wzrostem liczby polonistycznych ośrodków akademickich powstających z myślą o obcokrajowcach zwiększa się zainteresowanie certyfikatami, rośnie też liczba krajów, z których pochodzą egzaminowani (zob. Miodunka 2016). Wpływ na to ma również fakt, że potwierdzona odpowiednimi zaświadczeniami znajomość języka jest jednym z warunków otrzymania obywatelstwa polskiego przez cudzoziemca w myśl Ustawy z dnia 2 kwietnia $2009 \mathrm{r}$. o obywatelstwie polskim (Dz.U. z 2012 r., poz. 161, art. 30 ust. 2).

Niezależnie jednak od znacznego rozwoju glottodydaktyki wizja polszczyzny jako języka o znaczeniu międzynarodowym, atrakcyjnego dla cudzoziemców, właściwie nie istnieje w świadomości samych Polaków. Według deklaracji stanowi ona niewątpliwie wartość, ale pokutuje przekonanie, że to język przeznaczony wyłącznie do komunikacji wewnątrz wspólnoty narodowej, język własny Polaków. Negatywnym skutkiem takiej postawy może być brak determinacji, by dbać o znajomość polszczyzny wśród młodszych pokoleń wychowywanych za granicą. W zglobalizowanej rzeczywistości ma ona niższą 
pozycję, zresztą nie tylko w stosunku do języka angielskiego, ale również i innych języków. Na te zagadnienia związane z postawami Polaków wobec własnego języka zwrócono uwagę w serii artykułów poświęconych potrzebom badań nad współczesną świadomością językową (Miodunka 2017; Pawłowski 2017; Sagan-Bielawa 2017). Autorów tych publikacji łączy przekonanie, że badania takie powinny kłaść nacisk na ekonomiczny i polityczny wymiar języka, zgodnie z jego poniższą definicją, według której język to:

jeden z podsystemów informacyjnych funkcjonujący w ramach systemu zarządzania państwem, umożliwiający procesy komunikacji interpersonalnej i społecznej w sferach administracji, gospodarki, kultury etc., a zarazem współtworzący wspólnotę użytkowników, jej prestiż i potencjał ekonomiczny (Pawłowski 2015: 148).

Zdaniem Władysława Miodunki potencjał polszczyzny jest ciągle niedoceniany, a ewentualne działania promocyjne i edukacyjne należy poprzedzić zbadaniem różnych aspektów świadomości językowej Polaków, zmieniającej się wszakże w warunkach globalnej i europejskiej wielojęzyczności. Proponuje on program badawczy o szerokim zakresie tematycznym, obejmujący nie tylko postulaty odnośnie do polityki językowej, deklaracje i opinie na temat języka, ale pokazujący także skutki określonych postaw. Jak stwierdza bowiem w swoim artykule Adam Pawłowski, przekonanie o niewielkiej mocy języka sprzyja również zmianom wewnątrzjęzykowym i swoistemu serwilizmowi językowemu, którego przykładem jest m.in. ograniczanie fleksji nominalnej zarówno w obcych, przeniesionych, jak i w rodzimych nazwach firm oraz produktów.

Świadomość potencjału czy pozycji języka opiera się częściej na utartych stereotypach niż na konkretnych danych, takich jak ogólna liczba użytkowników danego języka, liczba uczących się go obcokrajowców, co pokazała ankieta skierowana do polskich studentów, zatytułowana Język polski w świecie (Sagan-Bielawa 2017). Przeprowadzono ją w 2016 r. w grupie 664 studentów Uniwersytetu Wrocławskiego, Uniwersytetu Jagiellońskiego, Akademii Górniczo-Hutniczej i Politechniki Śląskiej. Wśród nich ok. 54\% respondentów stanowili studenci kierunków humanistycznych i społecznych, natomiast niecałe $46 \%$ - studenci kierunków technicznych i przyrodniczych. Niniejszy artykuł kontynuuje prezentację wniosków z tej ankiety. Przedmiotem opracowania są nieopublikowane wcześniej wyniki części składającej się z dwóch pytań otwartych: „Dlaczego obcokrajowcy uczą się języka polskiego? Proszę wymienić najważniejsze motywacje” oraz „Czy Polska może mieć jakieś korzyści z faktu, że inni znają nasz język i posługują się nim? Jeśli tak, proszę napisać jakie".

Pytania ankiety miały na celu sprawdzenie, jaka jest ewentualna wartość rynkowa polszczyzny. Czy, zdaniem studentów, umiejętność posługiwania się danym językiem stanowi wyłącznie zysk jednostronny, związany z indywidualną sytuacją i planami życiowymi obcokrajowca? Czy Polakom opłaca się poświęcać czas i fundusze na promocję języka za granicą, wspieranie ośrodków nauczania, czy te nakłady mogą się nam w jakiś sposób zwrócić? Zadane studentom pytania otwarte nie narzucały kierunku myślenia, 
nie sugerowały, o jakie korzyści czy motywacje w uczeniu się i w nauczaniu języka polskiego chodzi. Dzięki temu respondenci demonstrowali własny sposób myślenia o języku i świadomość funkcji, jakie się językowi przypisuje.

W odróżnieniu od wcześniejszej publikacji Polszczyzna (nie tylko) dla Polaków. Pozycja języka w świecie w opinii studentów (Sagan-Bielawa 2017), która zawierała interpretację odpowiedzi zamkniętych, niniejszy artykuł opiera się na materiale zebranym w odpowiedziach na pytania otwarte. Obie prezentacje wyników różni zatem nie tylko treść i forma pytań, ale także metoda opracowania zebranego materiału. Analiza odpowiedzi otwartych jest trudniejsza niż zamkniętych, w których respondent nie wychodzi poza proponowany zestaw punktów. Swoboda kształtowania wypowiedzi, ich indywidualny charakter, często ogólnikowość, a niekiedy niezbyt wprawna forma nie ułatwiają kategoryzacji zebranego materiału. Analizując ankiety, zwrócono uwagę na powtarzające się sformułowania, wyrazy i wyrażenia, które wydają się pełnić funkcję słów kluczy, zakorzenionych w świadomości społecznej, utrwalających wspólne przekonania. Na tej podstawie wyodrębniono 13 kategorii motywacji do uczenia się polskiego oraz 11 kategorii korzyści, jakie wynikają z tego dla Polski (zob. Aneks). W drugim zestawieniu (tab. 2) uwzględniono liczbę ankiet, w których brak rozwiniętych odpowiedzi, ponieważ wskazanie rubryki „tak” lub „raczej tak” bez wymaganego uzasadnienia również stanowi problem badawczy. Większość ankietowanych podawała kilka czynników, łączyła je w związki przyczynowo-skutkowe, rozbudowywała argumentację w sposób, który pozwala zaliczyć te wypowiedzi do więcej niż jednej kategorii.

W ankiecie wyróżnia się dwa rodzaje funkcji języka: 1) język jest niezbędnym środkiem porozumiewania się; 2) język jest nośnikiem kultury, składnikiem tożsamości zbiorowej. Funkcje te się nie wykluczają, a nawet uzupełniają, co pokazuje np. następująca opinia: „Polakom dzięki temu będzie łatwiej dogadywać się za granicą oraz poza granicami naszego kraju będzie większa świadomość naszej kultury" (K22 tech.)․ Podkreśla ona funkcję komunikatywną języka, czysto użytkową, kiedy celem jest przekazywanie informacji, „dogadywanie się”, a jednocześnie kieruje uwagę na wartość symboliczną, poznawczą języka, na fakt, że pośredniczy on w dostępie do kultury. Przyglądając się dokładniej wynikom ankiety, można zauważyć, że podejście praktyczne przeważa $\mathrm{w}$ określaniu indywidualnych motywacji do uczenia się języka polskiego. Przekonanie, że polszczyzna to klucz do polskiej kultury, dominuje w odpowiedziach na temat korzyści dla kraju.

Według respondentów obcokrajowcy uczą się języka polskiego przede wszystkim po to, żeby podjąć pracę w Polsce (zob. tab. 1) - tak odpowiedziało 367 osób. O migracji i staraniach o obywatelstwo jako motywacji, a także bardziej szczegółowo: o potrzebie skutecznej integracji i asymilacji w nowym miejscu napisały łącznie 174 osoby,

\footnotetext{
${ }^{1}$ Skróty w nawiasie oznaczają płeć ( $\mathrm{K}$ - kobieta, $\mathrm{M}$ - mężczyzna) oraz profil studiów (hum. — kierunki humanistyczne lub społeczne, tech. - kierunki ścisłe, techniczne i przyrodnicze); liczby określają wiek. Cytaty $\mathrm{z}$ ankiet są podane $\mathrm{w}$ oryginalnej formie. Podkreślenia zostały wprowadzone przez autorkę.
} 
natomiast 168 osób wymieniło chęć studiowania, uczenia się w naszym kraju. Poza najczęściej podawaną frazą ,„praca w Polsce” pojawiły się również stwierdzenia mówiące generalnie o rozwoju zawodowym, lepszym wykształceniu, wyższych kwalifikacjach i poprawie sytuacji materialnej, co niekoniecznie musi wiązać się z pobytem w naszym kraju. Ponieważ trudno to jednoznacznie interpretować, 37 takich odpowiedzi ujęto jako odrębną kategorię „rozwój zawodowy”.

W opinii 123 osób uczenie się polskiego może być pasją „samą w sobie”, nowym hobby, rozrywką i - jak to często określano - wyzwaniem. Powtarza się przy tym stereotyp polszczyzny jako języka trudnego, którego trwałość potwierdzają badania sondażowe (zob. Sagan-Bielawa 2017: 24). Wyzwaniem jest bowiem, jak zaznaczyło 11 osób, nauka trudnego, a nawet „bardzo trudnego" języka, ,jednego z najtrudniejszych w świecie". Natomiast 60 studentów jako motywację wewnętrzną wskazywało także chęć poznania polskiej kultury.

Względy osobiste, związki rodzinne pojawiły się ogółem w 231 ankietach i te odpowiedzi zostały podzielone na trzy kategorie. Wśród nich przeważała jedna: „partner (małżonek/ukochana/druga połowa itp.) z Polski” (111 osób). Znalazły się tu również wskazania na pochodzenie uczącego się — ,język przodków”, „korzenie” (75 osób). Są także bardziej ogólne sformułowania, jak ,powiązania rodzinne”, „rodzina” (45 osób), które mogą dotyczyć zarówno aktualnej sytuacji osobistej, jak i odległej historii rodzinnej. Dlatego w tabeli 1. zostały one wymienione jako oddzielna, trzecia kategoria odnosząca się do relacji rodzinnych.

Pozostałe typy odpowiedzi są mniej liczne: 39 osób odpowiedziało, że o podjęciu nauki języka polskiego decyduje potrzeba sprawnego porozumiewania się z Polakami, 15 osób wymieniło częste kontakty z Polakami, znajomości. Inne odpowiedzi to: pasje podróżnicze i turystyka (9 osób), wzrastająca pozycja gospodarcza Polski, prestiż kraju, „moda na Polskę" (8 osób).

W poglądach respondentów przeważa pragmatyzm i utylitarne podejście do umiejętności posługiwania się polszczyzną. Obcokrajowcy chcą znać język, ponieważ muszą posługiwać się nim na co dzień, jeśli pracują, przebywają w tym kraju, weszli do miejscowej społeczności, do rodziny. Nie bez znaczenia pozostają kwestie sentymentalne czy intelektualne, które nie wiążą się z przymusem ekonomicznym, ale wydają się istotniejsze dla osób o zainteresowaniach humanistycznych.

W przypadku najczęściej podawanych rodzajów motywacji słuchacze studiów o profilu humanistycznym nie różnili się zasadniczo w swoich opiniach od studentów kierunków ścisłych. Odsetek odpowiedzi w obydwu grupach był zbliżony, różnił się o 1-2 punkty procentowe ${ }^{2}$. Praca została wymieniona w ok. $56 \%$ ankiet humanistów i w ponad $54 \%$ ankiet studentów kierunków ścisłych, migracja — odpowiednio w 26,5\% i 26\% ankiet. Wyraźne różnice, które mogą mieć związek z typem studiów,

\footnotetext{
${ }^{2} \mathrm{~W}$ artykule odsetek odpowiedzi jest liczony oddzielnie dla każdego profilu: $\mathrm{N}=362$ dla ankiet $\mathrm{z}$ kierunków humanistycznych i społecznych, N=302 dla kierunków ścisłych. Wartości procentowe są podawane w przybliżeniu, zasadniczo bez miejsc po przecinku.
} 
można zauważyć w wypadku dwóch rodzajów motywacji: chęć poznania języka i poznawanie kultury. Zainteresowanie samym językiem zostało wymienione w $22 \%$ ankiet na kierunkach humanistycznych, zainteresowanie polską kulturą — w ok. 12\%. Natomiast w przypadku drugiej grupy studentów (nauki ścisłe i przyrodnicze) jest to odpowiednio: $14 \%$ i $5 \%$ ankiet.

Wskazania na symboliczną wartość polszczyzny jako klucza do kultury przeważają w odpowiedziach na drugie pytanie — o ewentualne korzyści dla Polski, jakie mogłyby wynikać ze znajomości języka wśród obcokrajowców. Pierwsza część pytania była zamknięta, wymagała zaznaczenia jednej z czterech podanych odpowiedzi, następną część polecenia kierowano wyłącznie do osób, które uprzednio wybrały „tak” lub „raczej tak”. W ankiecie 257 osób odpowiedziało „tak”, 275 — „raczej tak”, 112 — „raczej nie”, 14 — „nie”3. Zestawienia uwzględniające profil kształcenia sugerują, że pozytywne efekty nauczania języka polskiego jako obcego częściej dostrzegają studenci kierunków humanistycznych i społecznych (około 46\% odpowiedzi „tak” i 39\% — „raczej tak”, ponad 13\% — „raczej nie” i poniżej 1\% — „nie”). Studenci kierunków technicznych i przyrodniczych wydają się bardziej sceptyczni, ostrożni w ocenach, w $45 \%$ odpowiedzieli „raczej tak”, w 30\% — „tak”, prawie 21\% — „raczej nie” i 4\% — „nie”. Ogółem 532 osoby powinny wymienić konkretne korzyści w dalszej części ankiety, jednak swoją opinię rozwinęło 400 respondentów, natomiast 132 osoby poprzestały na pozytywnych deklaracjach w pierwszej części (można powiedzieć, że są to „puste” deklaracje) - jest to najliczniejsza kategoria odpowiedzi (zob. tab. 2) i przeważają tu studenci kierunków ścisłych.

Jak już wspomniano, najczęściej uznawano, że popularność polszczyzny jako języka obcego dobrze służy promocji polskiej kultury. W 108 ankietach znalazły się argumenty tego rodzaju: „Poprzez język poznaje się kulturę narodu, w związku z tym mogą promować np. u siebie” (M21 hum.), ,poznawanie naszej kultury i promowanie jej w swoich ojczystych krajach i na świecie” (M25 hum.), ,rozpowszechnienie naszej kultury i tradycji” (M21 tech.), „rozpropagowanie historii i tradycji” (K19 hum.), ,popularyzacja kultury naszego kraju” (K21 hum.), ,wzrost świadomości o kulturze i tradycji polskiej” (M24 hum.). Trzykrotnie pojawiło się lakoniczne określenie świadomość kulturowa, np. „większa świadomość kulturowa, historyczna” (K19 hum.). Napisano m.in., że uczenie się języka obcego ,jest wyrazem szacunku dla narodu/kultury” (M22 tech.), obcokrajowcy „promują nasz kraj, mogą lepiej poznać polską kulturę i lepiej zrozumieć mentalność” (K19 hum.), „inni poznając nasz język poznają także kulturę przez co mogą stać się dla nas bardziej tolerancyjni i otwarci, co może skutkować większą akceptacją Polaków za granicą” (K20 hum.). Pozytywne skutki to „lepsze zrozumienie naszej kultury” (K23 hum.), ,większe zrozumienie polskiej kultury i obyczajów” (M30 tech.), ,zrozumienie polskiej specyfiki, mentalności” (M24 hum.). Jak podpowiada wieloznaczność używanego w ankietach słowa zrozumienie, rola języka w życiu społecznym jest złożona. Zrozumieć to nie tylko 'uświadomić sobie znaczenie wyrazu,

\footnotetext{
${ }^{3}$ Sześciu studentów pominęło ten punkt ankiety.
} 
wypowiedzi, istnienie relacji między rzeczami, zjawiskami itp.'; zrozumienie oznacza także 'wyrozumiałość, życzliwy stosunek do kogoś lub czegoś' (SJP PWN 2018).

Część wypowiedzi z tej kategorii wyraża podejście marketingowe do języka i kultury: „można sprzedawać kulturę” (M23 hum.), „będzie łatwiej «sprzedawać» polską kulturę za granicą” (M23 tech.), ,reklama, szersza znajomość naszego języka to szersza znajomość naszej kultury” (M24 tech.), „wzrasta zainteresowanie naszą kulturą, oznacza to, że Polska jest liczącym się krajem” (M20 hum.), „więcej ludzi zna język $\rightarrow$ zna kulturę $\rightarrow$ promocja” (K20 hum.). Mimo że rentowność wydaje się kategorią „niehumanistyczną" (por. Pawłowski 2015: 149-150), studenci są w stanie docenić moc języka przeliczaną na wymierne korzyści materialne. „Rozszerzenie wpływu kulturowego na inne państwa. Paradoksalnie jest to wyznacznik cywilizacyjny” - napisał jeden ze studentów (M23 hum.).

W 95 ankietach wyrażano zdanie, że większa popularność języka podnosi pozycję, prestiż, wpływa pozytywnie na wizerunek kraju, ułatwia jego rozwój. Z udaną promocją i rozwojem ekonomicznym kraju łączono właśnie oddziaływanie kulturowe, np.: ,większe zainteresowanie naszym krajem, w tym językiem, a przez to i kulturą sprzyja rozwojowi i inwestycjom zagranicznym” (K25 hum.), „sławny język $\rightarrow$ sławny kraj $\rightarrow$ bogaty kraj” (M23 tech.), „większe wpływy kulturowe na świecie = większe wpływy w ogóle = większe znaczenie, prestiż kraju = lepszy rozwój” (M24 hum.), „oddziaływanie kulturowe na mieszkańców innych krajów, tzw. «soft power»; - korzyści gospodarcze spowodowane zainteresowaniem krajem" (M22 tech.). Jeden z ankietowanych odpowiedział w sposób, który zdradza, że najchętniej widziałby korzyści materialne, ale tych jego zdaniem nie ma: „Większe zainteresowanie naszą rodzimą sztuką (literatura, filmy), a może innymi polskimi produktami. Przede wszystkim jednak większy prestiż i nic poza tym" (M27 hum.). Jako uzupełnienie tego punktu można dodać opinię wyrażoną w uwagach na zakończenie ankiety. Kładzie ona nacisk na moc języka, jednak w odniesieniu do sytuacji polszczyzny — również jako języka narodowego — brzmi pesymistycznie:

Nikt nie będzie uczył się j. polskiego jeżeli nie będzie się to wiązało z awansem cywilizacyjnym i kulturowym. Obecnie w j. polskim nie powstają na tyle znaczące wytwory intelektualne. Poza tym umiejętność posługiwania się j. polskim jest na niskim poziomie w dzisiejszych czasach (M22 tech.).

Po tej surowej ocenie trzeba przypomnieć i podkreślić, że pod względem liczby odpowiedzi kategoria dotycząca wpływu kulturowego przewyższa pozostałe, ale z drugiej strony - przegrywa ze 126 ankietami negującymi istnienie jakichkolwiek korzyści dla Polski oraz ze 132 odpowiedziami pozytywnymi „tak”/,raczej tak”, którym nie towarzyszy uzasadnienie tego wyboru.

Warto zauważyć, że pytanie o korzyści wyzwala myślenie w kategoriach marketingowych, kojarzy się z transakcją kupna-sprzedaży. Dowodzą tego zacytowane wcześniej przykłady, w których respondenci pisali dosłownie o sprzedawaniu kultury, produkcie. Terminy promocja czy promowanie zostały użyte 33 razy, w połączeniach: promocja 
kultury, promocja kraju, promocja języka. Pojawiły się określenia reklama (3), wizerunek (2), a także marka: „promocja kultury przekłada się bezpośrednio na budowanie «marki» kraju” (M26 hum.). W 14 ankietach użyto stosowanych w marketingu terminów rozpoznawalność i rozpoznawalny, np.: ,staje się bardziej popularny [język], co sprawia, że również Polska jako kraj będzie bardziej rozpoznawalna, ceniona” (K20 hum.), „kraj jest rozpoznawalny” (K20 hum.), „będziemy bardziej rozpoznawalni” (M25 tech.), „rozpoznawalność na arenie międzynarodowej” (M21 tech.).

W ankiecie chętnie wskazywano też doraźne, indywidualne korzyści związane z funkcją komunikatywną języka. Studenci stosunkowo często demonstrowali postawę utylitarną. Nie tylko lżej jest żyć w naszym kraju cudzoziemcowi władającemu polszczyzną, ale nam również jest łatwiej w świecie. „Łatwiejsza komunikacja”, „łatwość komunikacji z obcokrajowcami”, „sprawniejsza komunikacja”, „łatwiejsze porozumiewanie się” to sformułowania powtarzające się w 73 ankietach, w $12 \%$ ankiet z kierunków ścisłych, w $10 \%$ z kierunków humanistycznych. Niekiedy dodawano, że chodzi o wygodę w podróży, podczas wakacji, np.: „ułatwienie kontaktu w lokalach usługowych, hotelach za granicą” (M21 tech.), ,łatwa komunikacja za granicą (np. Chorwacja)” (K23 tech.). Były to najpopularniejsze odpowiedzi wśród studentów kierunków niehumanistycznych. Żaden inny typ argumentacji nie pojawiał się u nich częściej.

Kategorie korzyści dla Polski, które znajdują się wyżej w ogólnym rankingu (zob. tab. 2), są dostrzegane przeważnie przez studentów kierunków humanistycznych i społecznych, rzadziej na kierunkach technicznych czy przyrodniczych. Promowanie kultury pojawiło się w ponad $21 \%$ ankiet w pierwszej grupie oraz w ok. $10 \%$ ankiet z drugiej grupy. Humaniści też zdecydowanie częściej pisali o wizerunku i prestiżu kraju. Pomijając deklaracje ,puste”, widzimy, że jest to druga pod względem liczebności kategoria odpowiedzi, ale tę korzyść z nauczania polskiego podkreśla prawie $20 \%$ humanistów, zaś w grupie studentów kierunków ścisłych mniej niż 8\%.

Na piątym miejscu znajduje się kategoria ,popularyzacja języka”. W 62 ankietach zaznaczono, że dzięki zainteresowaniu obcokrajowców poprawia się sytuacja samego języka. Nie tylko staje się bardziej znany, ale ma szansę w ogóle przetrwać, np.: „nasz język się rozpowszechnia” (M21 tech.), ,podniesienie prestiżu naszego języka” (M22 hum.), „zostaje w użyciu” (K22 tech.), „dłuższe utrzymanie się języka, większa szansa na rozprzestrzenienie się języka" (M23 tech.). Również ten argument był wymieniany głównie przez humanistów - 14\% ankiet w tej grupie. Odsetek odpowiedzi w drugiej grupie to ok. $4 \%$.

Ponadto odpowiadano ogólnie, że korzyścią są kontakty handlowe i biznesowe (54 osoby), rozwój gospodarczy kraju i inwestycje zagraniczne (48 osób), pozyskanie pracowników (36 osób). Wymieniano też współpracę międzynarodową, kontakty międzynarodowe (36 osób), ale bez podawania szczegółów; nie wiadomo, jaki charakter i zasięg miałaby mieć ta współpraca. Zdaniem 34 respondentów popularność polszczyzny sprzyja rozwojowi turystyki, ponieważ — jak napisał jeden z nich — „chętniej przyjeżdża się do jakiegoś kraju (w celach turystycznych), jeśli chociaż w najmniejszym stopniu zna się jego język" (K21 hum). W ośmiu ankietach pisano ogólnikowo 
o korzyściach politycznych, w sześciu — o większej otwartości i łatwiejszej asymilacji cudzoziemców w naszym kraju.

Podsumowując opinie o korzyściach z uczenia się i nauczania języka polskiego jako obcego, można zastanawiać się nad trwałością, rozpowszechnieniem oraz nad źródłem poglądów na temat języka. Uwzględnienie w analizie profilu studiów pozwala zauważyć, że zasadniczo studenci nie różnią się między sobą we wskazywaniu motywacji, jakie ma cudzoziemiec uczący się języka. Wydają się one oczywiste, język jest narzędziem codziennej komunikacji, jego znajomość jest koniecznością w Polsce. Motywacja, którą rzadziej dostrzegają studenci takich kierunków, jak matematyka, informatyka, geologia, to fascynacja samym językiem i kulturą.

Kierunek studiów i zapewne związane z nim zainteresowania wpływają znacząco na różnice w przypadku pytania: „Czy Polska może mieć jakieś korzyści z faktu, że inni znają nasz język i posługują się nim?”. Negatywnych odpowiedzi jest więcej w ankietach wypełnianych na Politechnice, AGH czy uniwersyteckich kierunkach ścisłych, tam też częściej unika się rozwijania deklaracji pozytywnych. Bardziej pragmatyczne podejście tych respondentów do języka zdradzają odpowiedzi mówiące o łatwiejszej - z punktu widzenia Polaków - komunikacji. Choć liczba wskazań w obu grupach była zbliżona, trzeba przypomnieć, że w grupie humanistów kategoria „łatwiejsza komunikacja” pojawia się mniej więcej o połowę rzadziej niż „promocja kultury” czy „wizerunek kraju”, natomiast studenci kierunków technicznych i przyrodniczych podawali taką odpowiedź częściej niż inne (zob. tab. 2). Humaniści chętniej podkreślają wartość kultury — nie tylko symboliczną — i oni wydają się bardziej przekonani co do możliwości skutecznej promocji kraju za pomocą języka. W pozostałych, rzadziej wskazywanych kategoriach korzyści — tj. turystyka, kontakty handlowe, pozyskanie pracowników — nie ma różnic; niezależnie od profilu studiów pojawiały się one w kilku procentach ankiet.

Porównując rezultaty ankiety z wynikami niektórych badań prowadzonych przez językoznawców wśród młodzieży, można zauważyć powtarzalność pewnych postaw oraz argumentacji respondentów, nawet jeśli zasadniczo cel i metoda badania są inne. Ciekawy materiał porównawczy znajdujemy np. w sondażach przeprowadzonych wśród dzieci migrantów z Polski (Czeniek 2015; Lipińska 2015). W sondażu Anny Czeniek młodzi ludzie, opisując własną motywację do uczenia się języka rodziców, argumentowali podobnie jak polscy studenci — respondenci omawianej tu ankiety widzący sytuację obcokrajowca niejako z zewnątrz. Ponad połowa młodzieży polonijnej odpowiedziała, że język może im się przydać w staraniach o miejsce na uczelni lub o pracę, w drugiej kolejności wskazywano związki rodzinne i kontakty towarzyskie, natomiast ,jedynie" — jak zaznaczyła badaczka — kilkanaście procent uznało, że język polski jest kluczem do polskiej kultury (Czeniek 2015: 97). W innych badaniach w środowisku młodzieży polonijnej powtarzały się opinie, że znajomość polszczyzny i mówienie po polsku są warunkami zachowania rodzinnej tradycji, którą należy też przekazać dzieciom (Lipińska 2015: 80-81). Tradycja i kultura, co pokazały z kolei ankiety krajowe, przeprowadzone przez Annę Łobos wśród studentów na Uniwersytecie 
Śląskim i Politechnice Śląskiej, mieszczą się w samej definicji języka, jest to bowiem „przejaw kultury i ducha narodu”, „dorobek kulturalny”, „część kultury i tradycji” (Łobos 2003: 172). W postawach Polaków wobec języka kluczowe wydaje się pojęcie tradycji, zarówno rodzinnej, jak i narodowej.

Rodzina, kultura i tradycja należą do polskich słów, które Michael Fleischer (2003) nazywa symbolami kolektywnymi. Stanowią je jednostki leksykalne o dużym ładunku emocjonalnym (negatywnym lub pozytywnym), mające znaczenie kulturowe, czyli znaczenie szersze niż znaczenie leksykalne ${ }^{4}$. Zdaniem Fleischera polskie wartości kolektywne są bardzo trwałe. W badaniach sprzed kilkunastu lat wartość semantyczna kultury była wyraźnie łączona z tradycją i dziedzictwem, i na odwrót — znaczenie tradycji podkreślano, odwołując się do pojęcia kultury (Fleischer 2003: 126-136). Podobnie lubelskie badania nad semantyką nazw wartości z lat 1990-2000 pokazały, że zdaniem ówczesnej młodzieży aspekt kulturowy (historia, kultura, tradycja, w 2000 r. także język) pozwala najlepiej scharakteryzować ,prawdziwą” Polskę, czyli 'taką, jaka jest lub jaka powinna być' w potocznym rozumieniu (Bartmiński 2006: 348-354). Jerzy Bartmiński podkreśla przy tym, że waga tych czynników — zwłaszcza języka — wzrosła w ciągu ostatniego dziesięciolecia XX w.

Pokazuje to również argumentacja młodych respondentów w ankiecie będącej przedmiotem niniejszego artykułu. Odpowiadając na pytanie o korzyści, jakie możemy mieć z faktu, że obcokrajowcy posługują się polszczyzną, odwoływali się oni do tego samego repertuaru symboli i wartości. Według studentów ważne jest lepsze zrozumienie naszej kultury, mentalności, ale i rozpowszechnienie polskiej tradycji czy znajomość historii. Jednocześnie trzeba podkreślić, że przynajmniej część z nich umiejętnie łączy ową konserwatywną postawę z urynkowionym podejściem do polszczyzny jako narzędzia promocji. I nie ma w tym zestawieniu sprzeczności — tradycja dobrze się sprzedaje.

\section{BIBLIOGRAFIA}

Bartmiński J. (red.) 2006: Język, wartości, polityka. Zmiany rozumienia nazw wartości w okresie transformacji ustrojowej w Polsce. Raport z badań empirycznych, Lublin: Wydawnictwo Uniwersytetu Marii Curie-Skłodowskiej.

Czeniek A. 2015: Język polski mniej lub bardziej dziedziczony. Czynniki wpływające na kompetencję językową dzieci polskich emigrantów, Poradnik Językowy 8, 90-100.

Fleischer M. 2003: Stabilność polskiej symboliki kolektywnej, [w:] Bartmiński J. (red.), Język w kręgu wartości. Studia semantyczne, Lublin: Wydawnictwo Uniwersytetu Marii Curie-Skłodowskiej, 107-143.

Lipińska E. 2015: Postawy młodzieży polonijnej wobec języka ojczystego i tożsamości etnicznej, Poradnik Językowy 8, 73-89.

Łobos A. 2003: Znaczenie pojęć język i państwo dla współczesnych studentów, Biuletyn Polskiego Towarzystwa Językoznawczego LIX, 169-175.

\footnotetext{
${ }^{4}$ Walery Pisarek (2003) określa je mianem słów sztandarowych.
} 
Miodunka W. 2016: Znajomość polszczyzny wśród cudzoziemców niepolskiego pochodzenia. O potrzebie metodologii badań, Poradnik Językowy 8, 45-60.

Miodunka W. 2017: O potrzebie opisu i kształtowania świadomości językowej współczesnych Polaków, Język Polski XCVII, 3, 5-18.

Pawłowski A. 2015: Promocja języka polskiego - między lingwistyką a marketingiem, Poradnik Językowy 8, 143-155.

Pawłowski A. 2017: Odmiana nazw niektórych firm i produktów jako przedmiot polityki językowej, Język Polski XCVII, 3, 35-47.

Pisarek W. 2003: Wybory słów sztandarowych jako kryterium stratyfikacji społeczeństwa, [w:] Bartmiński J. (red.), Język w kręgu wartości. Studia semantyczne, Lublin: Wydawnictwo Uniwersytetu Marii Curie-Skłodowskiej, 87-106.

Sagan-Bielawa M. 2017: Polszczyzna (nie tylko) dla Polaków. Pozycja języka w świecie w opinii studentów, Język Polski XCVII, 3, 19-34.

SJP PWN — Słownik języka polskiego PWN < sjp.pwn.pl> [16.03.2018].

\begin{tabular}{|c|c|c|c|}
\hline \multirow[b]{3}{*}{ Motywacja } & \multicolumn{3}{|l|}{ ANEKS } \\
\hline & \multicolumn{3}{|c|}{ Liczba odpowiedzi } \\
\hline & Ogółem & $\begin{array}{l}\text { Kierunki } \\
\text { hum. i społ. }\end{array}$ & $\begin{array}{l}\text { Kierunki } \\
\text { ścisłe }\end{array}$ \\
\hline Praca w Polsce & 367 & 203 & 164 \\
\hline Migracja, obywatelstwo & 174 & 96 & 78 \\
\hline Studia/edukacja w Polsce & 168 & 89 & 79 \\
\hline Chęć poznania nowego języka & 123 & 80 & 43 \\
\hline Partner z Polski & 111 & 63 & 48 \\
\hline Polskie pochodzenie & 75 & 50 & 25 \\
\hline Poznawanie kultury & 60 & 44 & 16 \\
\hline Powiązania rodzinne (nieokreślone) & 45 & 27 & 18 \\
\hline Sprawna komunikacja z Polakami & 39 & 22 & 17 \\
\hline Rozwój zawodowy & 37 & 29 & 8 \\
\hline Znajomi Polacy & 15 & 13 & 2 \\
\hline Turystyka, podróże & 9 & 4 & 5 \\
\hline Pozycja Polski & 8 & 6 & 2 \\
\hline
\end{tabular}

Tabela 1. Dlaczego obcokrajowcy uczą się języka polskiego?

Źródło: badania własne. 


\begin{tabular}{|l|l|l|l|}
\hline \multirow{2}{*}{ Kategorie korzyści } & \multicolumn{3}{l}{ Liczba odpowiedzi } \\
\cline { 2 - 4 } & Ogółem & $\begin{array}{l}\text { Kierunki } \\
\text { hum. i społ. }\end{array}$ & $\begin{array}{l}\text { Kierunki } \\
\text { ścisłe }\end{array}$ \\
\hline Brak odpowiedzi & 132 & 51 & 81 \\
\hline Promocja kultury (tradycji, historii) & 108 & 77 & 31 \\
\hline Wizerunek kraju, prestiż & 95 & 72 & 23 \\
\hline Łatwiejsza komunikacja & 73 & 37 & 36 \\
\hline Popularyzacja języka & 62 & 50 & 12 \\
\hline $\begin{array}{l}\text { Ułatwienie w kontaktach handlowych } \\
\text { i biznesie }\end{array}$ & 54 & 38 & 16 \\
\hline Rozwój gospodarki, inwestycje & 48 & 28 & 20 \\
\hline Pozyskanie pracowników & 36 & 24 & 12 \\
\hline Współpraca międzynarodowa & 36 & 25 & 11 \\
\hline Rozwój turystyki & 34 & 23 & 11 \\
\hline Inne & 14 & 11 & 3 \\
\hline
\end{tabular}

Tabela 2. Czy Polska może mieć jakieś korzyści z faktu, że inni znają nasz język i posługują się nim? Jeśli tak, to jakie?

Źródło: badania własne.

\section{ABSTRACT}

On the advantages of teaching and learning Polish as a foreign language (results of the survey)

Keywords: language policy, linguistic consciousness, public opinion poll, Polish as a foreign language, promotion of Polish.

The article continues discussion of the results of the attitude research conducted among students of the Jagiellonian University, University of Wrocław, AGH University of Science and Technology, Silesian University of Technology. This paper examines two open-ended questions of the survey: 1) what is the main motivation of foreigners for learning Polish (from the point of view of native speaker); 2) whether the fact that foreigners speak our language provides any real benefits to us. The respondents realise not only practical, market but also symbolic value of language. In students' opinion language gives a huge insight into culture and tradition, it is considered to impact on image of the country and its economic development. The attitudes of the students towards language seemed to be related to some degree with their field of study. 